\title{
PENGEMBANGAN MEDIA PEMBELAJARAN PENGENALAN SISTEM OPERASI BERBASIS ANDROID
}

\author{
Ridho Dedy Arief Budiman ${ }^{1}$, Nurbani ${ }^{2}$ \\ ${ }^{1,2}$ Program Studi Pendidikan Teknologi Informasi dan Komputer \\ Fakultas Pendidikan MIPA dan Teknologi IKIP PGRI Pontianak \\ Jalan Ampera Nomor 88 Pontianak - 78116 \\ e-mail: ridho.asytarrazi@gmail.com
}

\begin{abstract}
Abstrak
Tujuan penelitian untuk mengembangkan media pembelajaran berbasis Android dengan tahapan analysis, design, development, implementation, dan evaluation. Subjek penelitian yaitu mahasiswa semester IV Pendidikan TIK IKIP PGRI Pontianak. Metode penelitian menggunakan research and development dengan pendekatan ADDIE. Instumen penelitian menggunakan angket. Teknik analisis data menggunakan deskriptif kuantitatif. Hasil penelitian yaitu: (1) Media pembelajaran yang dikembangkan dapat diterapkan berdasarkan hasil pada tahapan analysis; (2) Media pembelajaran berhasil dirancang pada tahapan design; (3) Media pembelajaran yang telah divalidasi dilakukan perbaikan sesuai saran dari validator pada tahapan development; (4) Media pembelajaran berhasil diterapkan ke subjek penelitian pada tahapan implementation; dan (5) Subjek penelitian menyatakan "Setuju" dan "Lebih Efektif' penggunaan media pembelajaran yang dikembangkan dalam proses pembelajaran.
\end{abstract}

Kata Kunci: pengembangan, media pembelajaran, Android.

\begin{abstract}
The research objective was to develop an Android-based learning media with stages of analysis, design, development, implementation, and evaluation. The subjects of the research were the fourth-semester students of ICT Education at IKIP PGRI Pontianak. The research method used research and development with the ADDIE approach. The research instrument used a questionnaire. Data analysis techniques using descriptive-quantitative. The results of the research: (1) The developed learning media can be applied based on the results at the analysis stage; (2) Learning media successfully designed at the design stage; (3) The validated learning media is improved according to the suggestions from the validators at the development stage; (4) Learning media successfully applied to respondents at the implementation stage; and (5) Respondents stated "Agree" and "More Effective" in the use of instructional media developed in the learning process.
\end{abstract}

Keywords: development, learning media, Android.

\section{PENDAHULUAN}

Revolusi Industri 4.0 telah memperkenalkan teknologi produksi massal yang fleksibel (Kagermann et al., 2013). Mesin akan beroperasi secara independen atau berkoordinasi dengan manusia (Sung, 2018). Fleksibilitas teknologi yang dapat berkoordinasi dengan manusia yang berkembang adalah teknologi smartphone. Perkembangan smartphone yang sangat pesat didukung dengan disertakannya 
teknologi terbaru dalam perangkat tersebut, sehingga menjadi sebuah peluang bagi institusi pendidikan. Salah satunya adalah dengan menyelenggarakan pembelajaran memanfaatkan media bergerak yang bisa digunakan di personal computer (PC) maupun di smartphone Android.

Faktor yang mendukung tercapainya tujuan pembelajaran adalah pemilihan media pembelajaran yang tepat. Pemilihan media pembelajaran yang tepat dimaksudkan agar pembelajaran tersebut sesuai dengan karakteristik mahasiswa maupun materi pembelajarannya. Oleh karenanya, seorang dosen harus mampu memilih media pembelajaran yang tepat guna mendukung proses pembelajaran yang diampu. Berdasarkan observasi yang dilakukan peneliti, diperoleh informasi bahwa dosen sudah mencoba menggunakan media pembelajaran dengan mengunduh animasi dari internet, namun mahasiswa hanya sebatas menggandakan media tersebut dan hanya membuka pada saat perkuliahan. Mahasiswa tidak membukanya kembali di luar perkuliahan dengan alasan tidak semua mahasiswa memiliki laptop atau komputer di rumah. Oleh karenanya, untuk menanggulangi masalah tersebut, inovasi sangat diperlukan dalam pengembangan media pembelajaran. Salah satunya yaitu membuat aplikasi media pembelajaran Android.

Ismayani (2018) menyebutkan salah satu perangkat yang populer dan sudah banyak digunakan sebagai media pembelajaran adalah perangkat berbasis Android. Android adalah sistem operasi mobile dan bersifat open source yang dikembangkan Google Corporation yang merupakan perusahaan mesin pencari terkemuka di dunia. Para pengembang dapat membuat aplikasi dengan menggunakan platform Android untuk berbagai perangkat bergerak. Android menjadi sistem operasi yang sangat populer karena tingkat efektivitas dan efisiensinya yang lebih baik dibandingkan dengan program sejenis lainnya, sehingga Android juga populer digunakan untuk kepentingan pendidikan karena kemudahan dan fleksibilitasnya.

Dosen diharapkan dapat membuat mahasiswa menjadi mengerti akan materi yang disampaikan. Hal tersebut dapat terjadi apabila ditunjang dengan proses pembelajaran yang efektif. Oleh karenanya diperlukan dosen yang ahli dalam 
bidangnya dan tidak melupakan informasi-informasi yang akan disampaikan. Ketika dalam proses pembelajaran, dosen menjelaskan materi dengan memberikan contoh-contoh dan terkadang terdapat beberapa hal yang terlewatkan dalam penyampaian tersebut. Apabila hal tersebut terjadi, dosen harus mengulang menjelaskan materi dalam proses belajar mengajar. Untuk mengatasi masalah tersebut, mahasiswa dapat disajikan media pembelajaran dalam bentuk gambar bergerak, teks yang jelas suara maupun urutan langkah pengerjaan yang sempurna dari rekaman yang diedit berulang-ulang agar didapatkan tujuan pembelajaran yang baik dan sempurna. Penyajian media tersebut dapat dilakukan dengan mengembangkan media pembelajaran berbasis Android. Briggs (Rusman, 2013) menyatakan bahwa media pembelajaran dapat digunakan sebagai sarana fisik untuk menyampaikan konten pengajaran, buku, film, dan kaset video.

Media pembelajaran telah menjadi bagian dari sarana pendukung dalam proses pembelajaran. Smaldino, et al. (2002) menyatakan bahwa media merupakan sarana komunikasi. Sanjaya (2008) menjelaskan bahwa media pembelajaran memiliki fungsi dan manfaat untuk: (1) Menangkap suatu objek atau peristiwa-peristiwa tertentu; (2) Memanipulasi keadaan, peristiwa, atau objek tertentu; dan (3) Menambah gairah dan motivasi belajar mahasiswa. Redondo, et al. (2013) menyatakan bahwa mahasiswa telah puas dan termotivasi oleh metodologi baru yang digunakan, serta teknologi dapat membantu meningkatkan prestasi akademik mahasiswa. Thitiporn (2015) menyatakan bahwa penerapan alat pembelajaran membuat siswa memahami materi dalam waktu yang lebih singkat.

Berdasarkan observasi dan wawancara yang dilakukan di Program Studi Pendidikan Teknologi Informasi dan Komputer (Prodi PTIK) IKIP PGRI Pontianak, $80 \%$ mahasiswa juga memanfaatkan smartphone hanya untuk berkomunikasi dan mengakses sosial media bahkan bermain game. Hal tersebut tentu saja berdampak tidak baik pada capaian pembelajaran setiap mata kuliah yang diajarkan. Namun demikian, berdasarkan hasil observasi yang dilakukan, terungkap bahwa mahasiswa telah siap apabila media pembelajaran berbasis Android diterapkan. Sesuai dengan hasil penelitian Budiman, dkk. (2018), bahwa 
kesiapterapan media pembelajaran berbasis augmented reality termasuk pada kategori "Siap".

Salah satu mata kuliah yang diajarkan di Prodi PTIK IKIP PGRI Pontianak adalah mata kuliah Sistem Operasi. Berdasarkan hasil pengamatan yang dilakukan pada materi Pengenalan Sistem Operasi, terungkap permasalahan yang terjadi, yakni belum maksimalnya penggunaan teknologi. Contohnya penggunaan media yang digunakan dalam perkuliahan hanya berupa modul pembelajaran (cetak dan file). Padahal, sebagian besar mahasiswa memiliki smartphone Android. Hal tersebut sesuai dengan hasil penelitian Arpan, dkk. (2018), bahwa dari 65 responden, hanya satu orang yang tidak memiliki smartphone Android atau sebesar 98,5\% responden memiliki smartphone Android.

Berdasarkan pada masalah yang telah diuraikan tersebut, maka diperlukan media pembelajaran inovatif yang digunakan dalam kegiatan pembelajaran di kelas. Oleh karenanya, peneliti melakukan penelitian tentang pengembangan media pembelajaran untuk materi Pengenalan Sistem Operasi berbasis Android.

\section{METODE}

Metode penelitian yang digunakan adalah research and development dengan pendekatan ADDIE. ADDIE merupakan singkatan dari Analysis, Design, Development, Implementation, dan Evaluation. Langkah-langkah pengembangan ADDIE terlihat pada gambar berikut (Sugiyono, 2015).

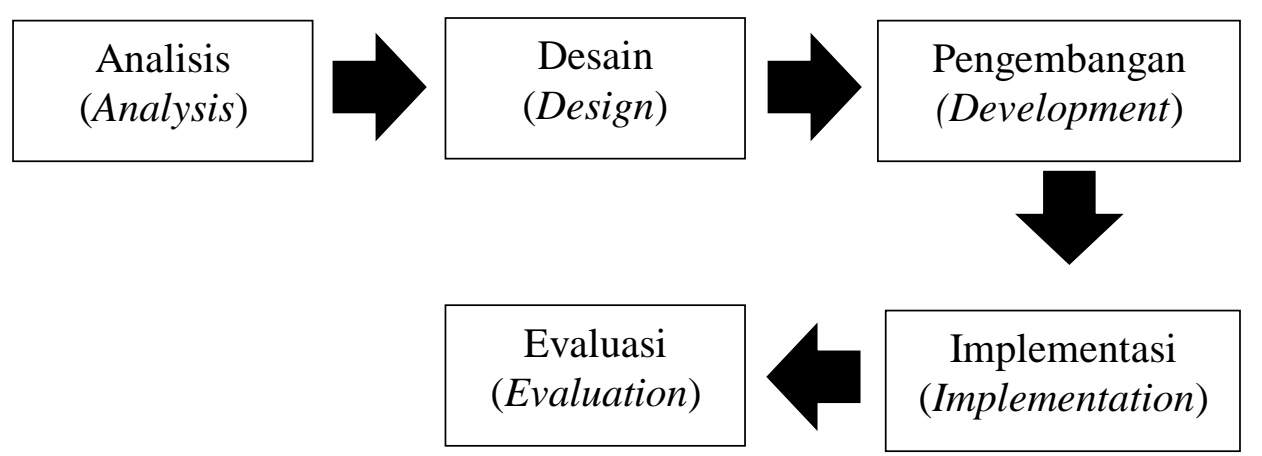

\section{Gambar 1 Langkah-Langkah Model Pengembangan ADDIE}

Analysis berkaitan dengan kegiatan analisis atau mengidentifikasi apa saja permasalahan yang ditemukan dalam lingkungan tertentu sehingga muncul ide atau gagasan dalam menentukan produk yang akan dikembangkan. Analisis 
kebutuhan pengguna diperlukan untuk menentukan siapa subjek pengguna media pembelajaran berbasis Android. Hasil analisis kebutuhan tersebut digunakan sebagai pedoman untuk mengembangkan aplikasi, yaitu menentukan tampilan dan kemudahan penggunaan yang sesuai dengan usia pengguna. Analisis konten berkaitan dengan isi dari aplikasi pembelajaran, yaitu materi yang relevan dengan tujuan pembelajaran. Terakhir, analisis kebutuhan hardware dan software untuk menentukan hardware dan software yang akan digunakan dalam pengembangan.

Design adalah tahap untuk merancang produk sesuai dengan kebutuhan atau analisis yang telah dilakukan sebelumnya. Dalam tahapan design, langkahlangkah yang dilakukan adalah menyusun daftar tugas seperti storyboard, tujuan pembelajaran, strategi pembelajaran, maupun mendesain antarmuka dalam sebuah aplikasi yang dapat dilekatkan pada smartphone Android dengan file ekstensi (.apk). Development merupakan kegiatan pengujian dan perbaikan aplikasi sesuai dengan hasil pengujian. Sebagai penentuan kualitas media dan materi dibutuhkan penilaian dari expert judgment yang terdiri dari ahli media dan ahli materi.

Implementation bertujuan untuk mempersiapkan lingkungan belajar yang melibatkan mahasiswa. Pada tahapan implementation, produk sudah siap untuk diterapkan dan disebarluaskan pada mahasiswa. Evaluation merupakan kegiatan untuk mengevaluasi dan menilai setiap langkah yang telah dilakukan supaya dapat tercapai produk yang sesuai spesifikasi yang ditetapkan dan untuk mengukur kualitas produk yang telah dikembangkan.

Subjek penelitian yaitu mahasiswa Program Studi Pendidikan TIK IKIP PGRI Pontianak semester IV tahun akademik 2018/2019 yang mengambil mata kuliah Sistem Operasi. Subjek uji coba skala kecil sebanyak 10 mahasiswa. Subjek implementasi sebanyak 65 mahasiswa. Instumen penelitian menggunakan angket dengan skala 4. Kriteria angket sebagai berikut (Arikunto, 1996).

Tabel 1 Kriteria Angket

\begin{tabular}{cc}
\hline Skor & Kriteria \\
\hline 4 & Sangat Baik \\
3 & Baik \\
2 & Cukup \\
1 & Kurang Baik \\
\hline
\end{tabular}


Data yang terkumpul diproses menggunakan rumus (Purwanto, 1996).

Persentase Kelayakan $(\%)=\frac{\text { Skor yang diperoleh }}{\text { Skor maksimum ideal }} \times 100 \%$

Data dianalisis dengan teknik analisis deskriptif kuantitatif yang diungkapkan dalam distribusi skor dan persentase terhadap kategori skala penilaian yang telah ditentukan. Kesesuaian aspek dalam pengembangan media pembelajaran dapat menggunakan kriteria pada Tabel 2 (Arikunto, 1996) .

Tabel 2 Tabel Skala Persentase

\begin{tabular}{cc}
\hline Persentase Pencapaian & Interpretasi \\
\hline $76-100 \%$ & Layak \\
$56-75 \%$ & Cukup layak \\
$40-55 \%$ & Kurang layak \\
$0-39 \%$ & Tidak layak \\
\hline
\end{tabular}

\section{HASIL DAN PEMBAHASAN}

Analysis

Informasi mengenai kebutuhan awal dalam mengembangkan media pembelajaran diperlukan: (1) Analisis Kebutuhan Pengguna; (2) Analisis Konten atau Isi; dan (3) Analisis Kebutuhan Hardware dan Software. Sebelum melalui tahap analisis kebutuhan pengguna, dilakukan identifikasi masalah dan menentukan solusi yang diperlukan. Berdasarkan hasil observasi pembelajaran di kelas, wawancara, dan penelitian terdahulu yang relevan, ditemukan permasalahan antara lain mahasiswa masih kesulitan dalam mempelajari pembahasan mata kuliah Sistem Operasi. Salah satu penyebabnya adalah belum menggunakan media belajar mandiri yang bervariasi. Pembuatan media pembelajaran dapat dijadikan solusi untuk mengatasi permasalahan yang terjadi.

\section{Analisis kebutuhan pengguna}

Analisis kebutuhan pengguna dilakukan untuk mengetahui kebutuhan untuk produk yang akan dikembangkan. Kebutuhan ditentukan berdasarkan data dari hasil observasi dan wawancara yang tertera pada Tabel 3. 
Tabel 3 Hasil Observasi dan Wawancara

\begin{tabular}{|c|c|c|}
\hline No. & $\begin{array}{l}\text { Hasil Pengamatan dan } \\
\text { Wawancara }\end{array}$ & Keterangan \\
\hline 1. & Mata kuliah yang diamati & Sistem Operasi. \\
\hline 2. & Proses Pembelajaran & Menerangkan, diskusi, presentasi, penugasan. \\
\hline 3. & $\begin{array}{l}\text { Ketersediaan buku atau } \\
\text { sumber belajar }\end{array}$ & $\begin{array}{l}\text { Harus mencari buku referensi ke perpustakaan dan } \\
\text { sumber lain berasal dari internet. }\end{array}$ \\
\hline 4. & $\begin{array}{l}\text { Kualitas media } \\
\text { pembelajaran }\end{array}$ & $\begin{array}{l}\text { Masih terbatas pada slide powerpoint yang } \\
\text { penggunaannya masih jarang, serta media yang } \\
\text { dipakai belum bervariasi. }\end{array}$ \\
\hline 5. & Kondisi Mahasiswa & $\begin{array}{l}\text { Kesulitan memahami materi dan dosen harus } \\
\text { menerangkan berulang-ulang; kesulitan mencari } \\
\text { sumber referensi. }\end{array}$ \\
\hline 6. & $\begin{array}{l}\text { Kendala dosen dalam } \\
\text { mengajar }\end{array}$ & $\begin{array}{l}\text { Mahasiswa kurang motivasi dalam belajar karena } \\
\text { pelajaran yang dirasa sulit; mahasiswa tidak } \\
\text { memperhatikan dan tidak serius belajar; mahasiswa } \\
\text { sibuk dengan smarphone masing-masing untuk } \\
\text { bersosial media dan bermain game. }\end{array}$ \\
\hline 7. & $\begin{array}{l}\text { Teknologi yang dimiliki } \\
\text { mahasiswa sebagai sumber } \\
\text { belajar mandiri }\end{array}$ & $\begin{array}{l}\text { Sebagian mahasiswa memiliki laptop tetapi lebih } \\
\text { banyak mahasiswa memiliki smartphone Android } \\
\text { yang belum dimafaatkan secara maksimal. }\end{array}$ \\
\hline 8. & Media yang dibutuhkan & $\begin{array}{l}\text { Media bantu yang dapat menarik minat dan } \\
\text { perhatian mahasiswa, bisa terdapat materi, video } \\
\text { untuk memperjelas materi, dan kuis untuk } \\
\text { menambah wawasan dalam skill belajar; media yang } \\
\text { juga dapat digunakan untuk belajar di rumah (dapat } \\
\text { dibawa pulang). }\end{array}$ \\
\hline
\end{tabular}

Hasil dari observasi dan wawancara tersebut kemudian dianalisis untuk menetapkan kebutuhan pengguna didukung spesifikasi/karakteristik media pembelajaran. Hal tersebut tercantum dalam Tabel 4.

Tabel 4 Hasil Analisis Kebutuhan Pengguna

\begin{tabular}{|c|c|}
\hline Kententuan & Hasil Analisis \\
\hline Sasaran pengguna & $\begin{array}{l}\text { Mahasiswa Program Studi Pendidikan TIK IKIP PGRI Pontianak } \\
\text { semester genap yang mengambil mata kuliah Sistem Operasi. }\end{array}$ \\
\hline $\begin{array}{l}\text { Jenis media } \\
\text { pembelajaran }\end{array}$ & $\begin{array}{l}\text { Media pembelajaran berbentuk aplikasi yang dapat dilekatkan pada } \\
\text { smartphone Android supaya dapat digunakan untuk belajar mandiri. }\end{array}$ \\
\hline $\begin{array}{l}\text { Fitur yang } \\
\text { dibutuhkan }\end{array}$ & $\begin{array}{l}\text { Menampilkan tujuan pembelajaran dan materi Pengenalan Sistem } \\
\text { Operasi; tersedia video tutorial instal ulang; terdapat kuis pilihan } \\
\text { ganda; terdapat halaman profil pengembang aplikasi; fitur bantuan } \\
\text { petunjuk penggunaan aplikasi }\end{array}$ \\
\hline
\end{tabular}

\section{Analisis kebutuhan konten}

Tahapan selanjutnya setelah identifikasi kebutuhan pengguna yaitu analisis konten atau isi. Analisis konten berkaitan dengan isi dari aplikasi pembelajaran, 
yaitu materi yang relevan dengan tujuan pembelajaran yang telah ditentukan. Dalam aplikasi sudah dicantumkan sumber dan tujuan pembelajaran. Selain menentukan materi, konten lain yang akan dimuat dalam media pembelajaran harus ditentukan terlebih dahulu, yaitu berupa video dan latihan soal berupa kuis. Video memuat cara pemasangan Sistem Operasi Windows 7, 8, dan 10. Materi yang akan disajikan pada media pembelajaran berbasis Android yaitu materi Pengenalan Sistem Operasi. Berdasarkan analisis kebutuhan pengguna, kuis disajikan supaya mahasiswa dapat menambah skill dalam belajar sehingga dapat meningkatkan pemahaman mahasiswa.

\section{Analisis kebutuhan hardware dan software pengembangan}

Analisis kebutuhan hardware dan software dilakukan untuk mendukung keberhasilan pembuatan media pembelajaran. Sebagai alat untuk mengembangkan aplikasi yang sesuai spesifikasi media pembelajaran tersebut, maka dibutuhkan software. Software yang digunakan adalah browser (Google Chrome, Mozilla Firefox, Uc Browser, dan Microsoft Edge) sebagai software utama dalam pembuatan media dengan nama web app.Thunkable.com. Untuk menghasilkan aplikasi dengan file berbentuk (.apk) yang dapat dilekatkan pada smartphone Android, cukup lakukan export dan otomatis akan menjadi file berbentuk (.apk). Software online seperti Youtube, Google Drive, dan WhatsApp juga bisa digunakan. Untuk menjalankan software tersebut tidak diperlukan spesifikasi hardware yang besar, cukup membuka aplikasi browser yang ada di laptop (PC).

\section{Design}

Hasil dari tahap design adalah: (1) Flowchart yang menggambarkan urutan dan struktur media pembelajaran; dan (2) Storyboard yang meliputi rencana desain template dan interface. Flowchart yang telah dibuat kemudian dijadikan pedoman untuk merancang storyboard sehingga dihasilkan rancangan yang sesuai dengan struktur media. Flowchart media yang dikembangkan sebagai berikut. 


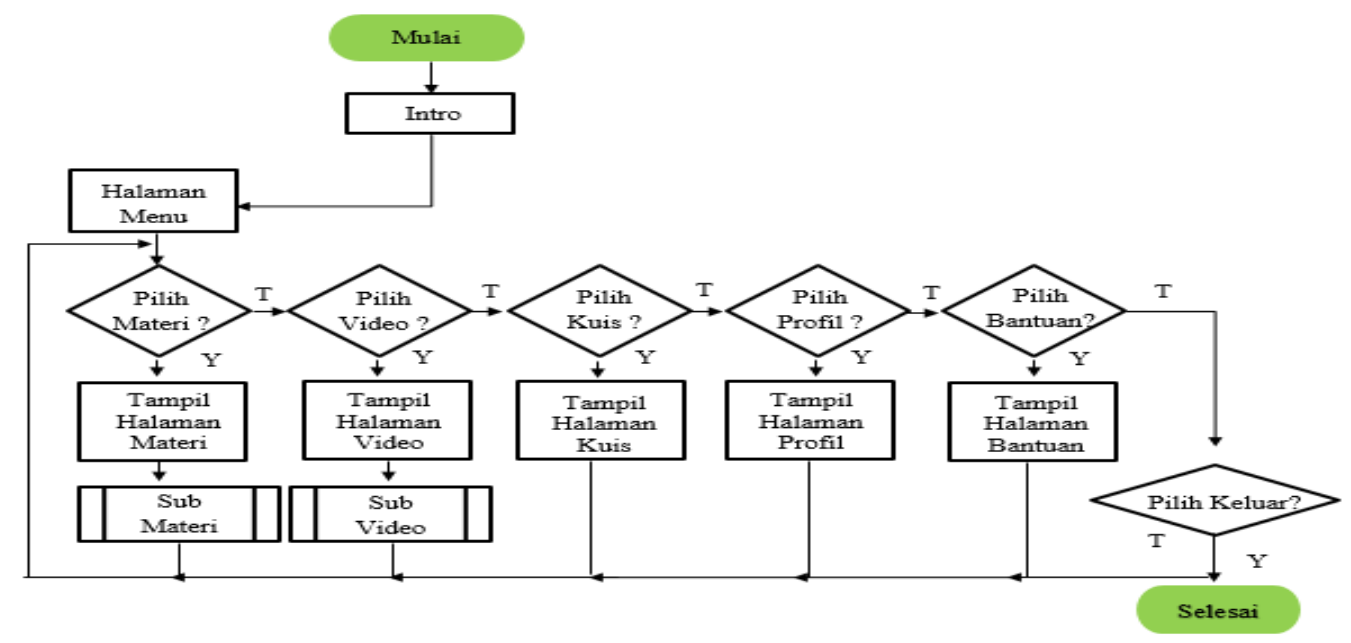

\section{Gambar 2 Flowchart Stuktur Media Pembelajaran}

Flowchart menggambarkan visualisasi runtutan konten yang terdapat dalam aplikasi. Pada awal dibukanya aplikasi, pengguna akan masuk ke halaman Intro yang berisi logo IKIP PGRI Pontianak. Kemudian pengguna akan diarahkan untuk masuk ke halaman Menu Utama yang terdapat berbagai macam tombol menu untuk menuju halaman tertentu. Halaman-halaman tersebut yaitu halaman menu Materi, Video, Kuis, Profil, dan Bantuan.

Halaman menu Materi berisi sub-sub materi, yaitu Tujuan Pembelajaran, Materi Sistem Operasi Lengkap, Jenis-Jenis Sistem Operasi (Disk Operating System, Windows, MAC OS, Linux, Unix, Apple IOS, Android, dan Windows Phone). Halaman menu Video yang berisi sub-sub video tutorial install ulang. Halaman menu Kuis berisikan soal mengenai materi yang berjumlah 20 soal. Soal akan diacak jika ada pengulangan pemilihan menu Kuis. Halaman menu Profil merupakan isi biodata pengembang. Halaman menu Bantuan merupakan petunjuk aplikasi penggunaan media.

\section{Development}

Development merupakan tahap pengembangan dan pengujian produk. Hasil dari analisis dan desain dikembangkan menjadi produk akhir. Berikut langkahlangkah yang dilakukan dalam tahapan development. 


\section{Pengembangan produk}

Desain yang telah dirancang selanjutnya dikembangkan dalam bentuk aplikasi menggunakan web Thunkable. File ekstensi dari Thunkable adalah (.aia) dan plugin ekstensinya (.aix). Plugin ekstensi isi berisi beberapa kode perintah dalam bahasa pemrograman Java (.java) yang akan diubah menjadi file plugin dengan ekstensi (.aix) yang berguna pada bagian extension. Berikut adalah hasil pengembangan produk.

\section{Tabel 5 Hasil Pengembangan Produk}

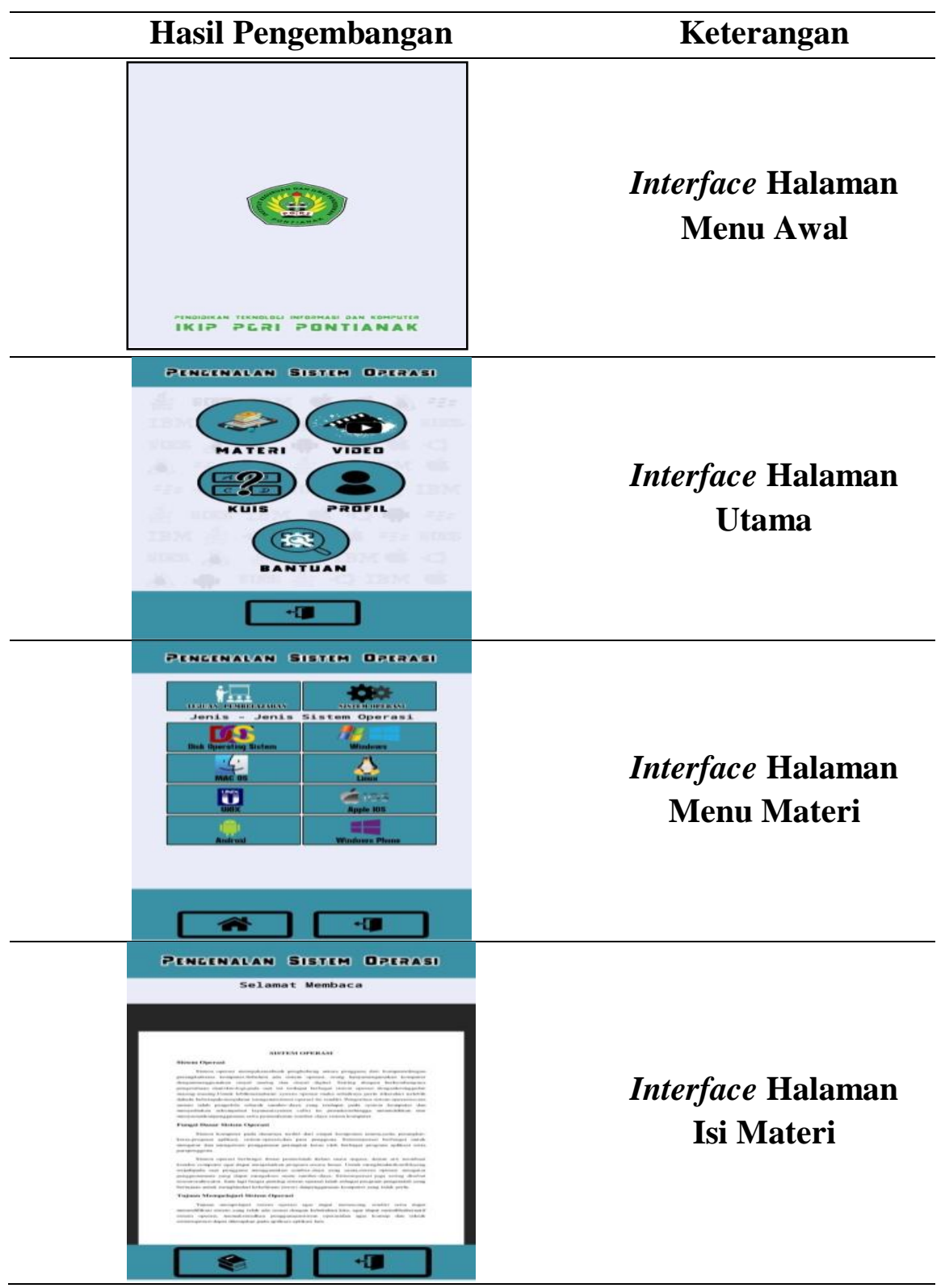




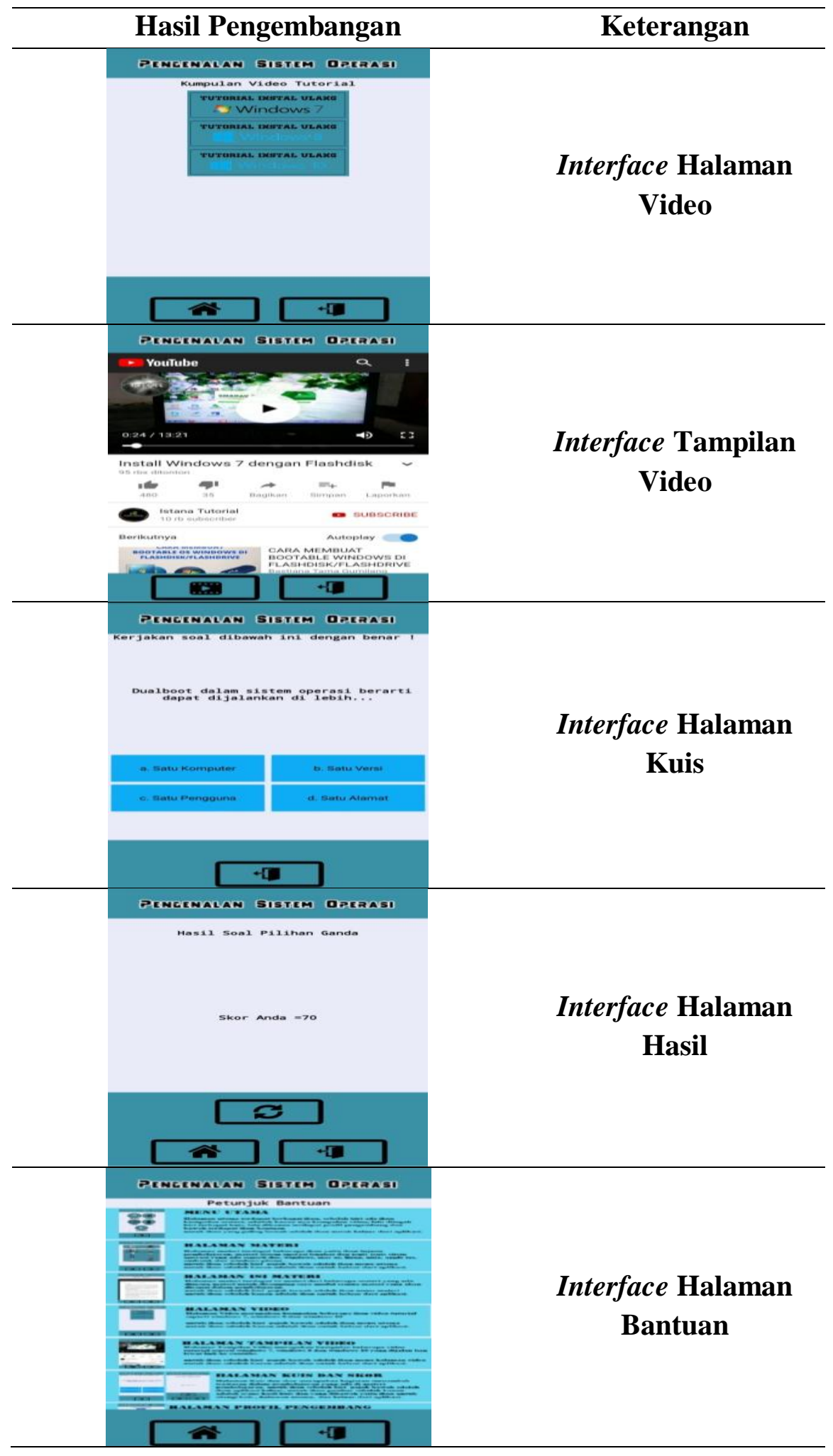




\section{Penilaian ahli media dan ahli materi}

Hasil rancangan media pembelajaran divalidasi oleh 2 (dua) orang ahli media dan 1 (satu) orang ahli materi. Berdasarkan hasil validasi media dan materi diperoleh bahwa media pembelajaran yang dirancang dalam kategori "Layak". Rancangan media pembelajaran dilakukan perbaikan sesuai dengan saran dan komentar dari ahli media dan materi. Setelah dilakukan perbaikan, maka media pembelajaran diuji cobakan ke 10 mahasiswa. Berdasarkan uji coba, diperoleh hasil bahwa media pembelajaran dalam kategori "Layak", sehingga media pembelajaran tersebut dapat dilanjutkan ke tahap implementasi. Hal tersebut sesuai dengan hasil penelitian terdahulu yang menyatakan bahwa media pembelajaran yang dikembangkan layak digunakan dalam proses pembelajaran (Dharmayanti dan Oktarika, 2019; Nurbani, dkk., 2019; Apriani, dkk., 2018; Armen dan Rahmadani, 2018; Pratama, 2018; Sari, dkk., 2018; Vivin, dkk., 2018; Matsun, 2015; Nurjayanti, 2015).

\section{Implementation}

Implementaion bertujuan untuk menerapkan produk aplikasi yang telah dikembangkan kepada subjek penelitian. Media pembelajaran berbasis Android yang telah melalui proses validasi ahli dan pengujian kelompok kecil dilakukan revisi sampai menghasilkan produk aplikasi yang siap diimplementasikan dan disebarluaskan. Aplikasi diimplementasikan kepada 65 mahasiswa. Pada saat diimplementasikan, media pembelajaran (aplikasi) berfungsi dengan baik (Matsun, dkk., 2018). Media pembelajaran berbasis Android pada mata kuliah Sistem Operasi yang berbentuk aplikasi dengan ekstensi (.apk) diunggah ke Google Drive yang merupakan layanan penyimpanan milik Google. Mahasiswa dapat mengunduh file (.apk) tersebut dan melekatkannya pada smartphone masing-masing.

\section{Evaluation}

Evaluation bertujuan untuk mengetahui kualitas pengembangan media pembelajaran berbasis Android. Evaluasi yang sebagian besar dilakukan adalah 
evaluasi formatif. Evaluasi dilakukan pada setiap tahap yang disebutkan sebelumnya. Tujuan dari evaluasi adalah untuk memperbaiki produk yang dibuat sebelum produk akhir diterapkan dan disebarluaskan. Salah satu tahap evaluasi adalah memperbaiki media pembelajaran yang dihasilkan dari tahap development, yaitu setelah dilakukan pengujian oleh ahli media, ahli materi, dan kelompok kecil sebagai subjek uji coba produk aplikasi.

Revisi yang dilakukan terhadap media pembelajaran berbasis Android sesuai dengan saran-saran yang diperoleh dari para validator, supaya menghasilkan produk akhir yang baik. Pada tahapan implementation, subjek penelitian diberikan angket respons. Berdasarkan angket respons tersebut, diperoleh hasil bahwa responden "Setuju" pembelajaran dengan media pembelajaran berbasis Android lebih tepat digunakan dibandingkan media yang sering digunakan oleh dosen.

Responden juga menyatakan bahwa media pembelajaran berbasis Android "Lebih Efektif” digunakan jika dibandingkan dengan media pembelajaran yang sering digunakan oleh dosen. Hal tersebut sesuai dengan hasil penelitian Arahim (2018), bahwa pembelajaran menggunakan lembar kerja siswa digital dengan visualisasi berbantukan macromedia flash lebih efektif daripada pembelajaran konvensional.

\section{SIMPULAN}

Berdasarkan analisis terhadap data penelitian, maka disimpulkan: (1) Media pembelajaran yang dikembangkan dapat diterapkan berdasarkan hasil pada tahapan analysis; (2) Media pembelajaran berhasil dirancang pada tahapan design; (3) Media pembelajaran yang telah divalidasi dilakukan perbaikan sesuai saran dari validator pada tahapan development; (4) Media pembelajaran berhasil diterapkan ke subjek penelitian pada tahapan implementation; dan (5) Subjek penelitian menyatakan "Setuju" dan "Lebih Efektif" penggunaan media pembelajaran yang dikembangkan dalam proses pembelajaran. 


\section{UCAPAN TERIMA KASIH}

Terima kasih peneliti ucapkan kepada semua pihak yang telah membantu dalam proses penelitian, khususnya kepada LPPM IKIP PGRI Pontianak yang telah membiayai penelitian untuk skim Penelitian Kompetitif tahun anggaran 2019 dan mahasiswa Program Studi Pendidikan TIK IKIP PGRI Pontianak semester IV tahun akademik 2018/2019 yang menjadi responden dalam penelitian.

\section{DAFTAR PUSTAKA}

Apriani, Daningsih, E., \& Yokhebed. 2018. Kelayakan Video Tutorial Pembuatan Donat Jahe Submateri Peran Tumbuhan di Bidang Ekonomi. Edukasi: Jurnal Pendidikan, 16(2): 255-266.

Arahim, I. A. 2018. Pengembangan Lembar Kerja Siswa dengan Visualisasi Berbantu Macromedia Flash pada Pembelajaran Matematika. Edukasi: Jurnal Pendidikan, 16(1): 116-123.

Arikunto, S. 1996. Prosedur Penelitian Suatu Pendekatan Praktik. Edisi Revisi. Jakarta: Rineka Cipta.

Armen, M. \& Rahmadani, A. F. 2018. Kualitas Materi dan Aspek Isi Media Pembelajaran Renang Gaya Bebas Berbasis Macromedia Flash 8 Siswa Kelas VII SMP. Jurnal Pendidikan Olahraga, 7(1): 54-67.

Arpan, M., Budiman, R. D. A., \& Verawardina, U. 2018. Need Assessment Penerapan Media Pembelajaran Pengenalan Hardware Jaringan Komputer Berbasis Augmented Reality. Edukasi: Jurnal Pendidikan, 16(1): 48-56.

Budiman, R. D. A., Arpan, M., \& Verawardina, U. 2018. Readiness Assessment Penerapan Media Pembelajaran Pengenalan Hardware Jaringan Komputer Berbasis Augmented Reality. Jurnal Pendidikan Informatika dan Sains, 7(1): 118-125.

Dharmayanti, W. \& Oktarika, D. 2019. Pengembangan Media Pembelajaran Berbasis Multimedia Interaktif untuk Guru IPA di Sekolah Menengah Pertama. Jurnal Pendidikan Informatika dan Sains, 8(1): 41-51.

Ismayani, A. 2018. Cara Mudah Membuat Aplikasi Pembelajaran Berbasis Android dengan Thunkable. Jakarta: Elex Media Komputindo.

Kagermann, H., Lukas, W. D., \& Wahlster, W. 2013. Recommendations for Implementing the Strategic Initiative Industrie 4.0. Industrie 4.0 Working Group.

Matsun. 2015. Pengembangan Media Pembelajaran Elektronika Lanjut pada Materi Gerbang Logika Menggunakan Adobe Flash. Jurnal Pendidikan Informatika dan Sains, 4(1): 99-111.

Matsun, Ramadhani, D., \& Lestari, I. 2018. Perancangan Media Pembelajaran Listrik Magnet Berbasis Android di Program Studi Pendidikan Fisika IKIP PGRI Pontianak. Jurnal Pendidikan Informatika dan Sains, 7(1): 107-117. 
Nurbani, Koriaty, S., \& Puspitasari, H. 2019. Pengembangan Modul Elektronik Mata Kuliah Sistem Digital untuk Program Studi Pendidikan TIK. Jurnal Pendidikan Informatika dan Sains, 8(1): 52-63.

Nurjayanti, A. I. 2015. Pengembangan Multimedia Pembelajaran Matematika Berbasis Android untuk Siswa Kelas 3 Sekolah Dasar. Artikel Ilmiah. Fakultas Teknik, Universitas Negeri Yogyakarta.

Pratama, A. 2018. Perancangan Media Pembelajaran Cross-Platform Instalasi Software pada Paket Keahlian Teknik Komputer dan Jaringan. Jurnal Pendidikan Informatika dan Sains, 7(1): 1-10.

Purwanto, N. 1996. Psikologi Pendidikan. Jakarta: PT Remaja Rosdakarya.

Redondo, E., Fonseca, D., Sanchez, A., \& Navaro, I. 2013. New Strategies Using Handheld Augmented Reality and Mobile Learning-Teaching Methodologies, in Architecture and Building Engineering Degrees. 2013 International Conference on Virtual and Augmented Reality in Education. Procedia Computer Science, 25 (2013): 52-61.

Rusman. 2013. Model-Model Pembelajaran. Jakarta: Rajawali Pers.

Sanjaya, W. 2008. Perencanaan dan Desain Sistem Pembelajaran. Jakarta: Kencana Prenada Media Group.

Sari, F. N. I., Darma, Y., \& Dafrita, I. E. 2018. Pengembangan Media Pembelajaran PowerPoint Integrasi Geogebra untuk Meningkatkan Kemampuan Representasi Matematis dalam Materi Refleksi. Edukasi: Jurnal Pendidikan, 16(2): 281-289.

Smaldino, S. E., Heinich, R., Molenda, M., \& Russel, J. D. 2002. Instructional Technology and Media for Learning $\left(9^{\text {th }}\right.$ ed). New Jersey: Pearson.

Sugiyono. 2015. Metode Penelitian Kuantitatif, Kualitatif, dan $R \& D$. Bandung: Alfabeta.

Sung, T. K. 2018. Industry 4.0: A Korea Perspective. Technological Forecasting and Social Change, 132(2018): 40-45.

Thitiporn, S. 2015. The Development of Model Learning Media of Sorting Algorithm. Elsevier Ltd.

Vivin, D., Daningsih, E., \& Marlina, R. 2018. Kelayakan PowerPoint Interaktif Organ Tumbuhan Kelas XI SMA Berdasarkan Analisis Ukuran dan Tipe Stomata. Edukasi: Jurnal Pendidikan, 16(2): 196-209. 